\title{
AMANDEMEN UNDANG-UNDANG DASAR 1945 SEBAGAI CARA UNTUK MEMPERKUAT PERANAN DAN KEDUDUKAN DEWAN PERWAKILAN DAERAH DI INDONESIA*
}

\author{
Eddie Prabowo, Bonafasius Aji K., dan Julius Caesar Barito*
}

\begin{abstract}
Abstrak
The role of Dewan Perwakilan Daerah (DPD) as subsystem of high state body has no proper power to representing regions in Indonesia. The DPD have only role restricted on the regional problems even have the same level with House of People Representative (DPR). It constituted under fourth amendment that has stipulated regarding People Consultative Assembly $(M P R)$ which consists of DPR and DPD. But in fact the DPD have limitative role to representing the whole of regional interests. It reflected on the narrow contribution of the DPD only towards legislation process regarding regional decentralisation, new regional forming, and development. On the author thought that all the effective law and regulations will affect to regional and the people interest but DPD has been reduced their role to protect that interests.
\end{abstract}

Kata kunci: hukum tata Negara, amandemen UUD 1945, peranan dan kedudukan dpd

\section{Latar Belakang}

Reformasi tahun 1998 menjadi momentum dalam perubahan tata negara Republik Indonesia yang telah lebih dari tiga puluh dipimpin oleh rezim Orde Baru. Perubahan yang paling mendasar adalah amandemen Undang-Undang Dasar Republik Indonesia. Amandemen Undang-Undang Dasar 1945 dinilai dapat membawa perubahan dalam sistem ketatanegaraan,

* Tulisan ini telah diikutsertakan dalam Pemilihan Peneliti Remaja LIPI yang diselenggarakan Lembaga Ilmu Pengetahuan Indonesia tahun 2007 dibawah bimbingan Bapak Fernando Manullang, S.H.

- Mahasiswa Fakultas Hukum Universitas Indonesia Program Reguler Angkatan 2004, 2003, dan 2005. 
untuk menyelesaikan permasalahan-permasalahan yang berkaitan dengan hukum tata negara di Indonesia.

Era Reformasi tersebut membuat perubahan yang revolusioner dalam bidang perundang-undangan. Dikatakan revolusioner, karena perubahan tersebut hampir mencapai $300 \%$. Secara teori, perubahan sebuah Undangundang hanya dapat dilakukan maksimal $50 \%$. Jika lebih dari itu, maka dapat dikatakan pergantian atau revolusi perubahan.'

Dalam perjalanan sejarah, sejak pemerintahan Orde Lama, Orde Baru hingga masa Transisi Demokrasi, aspirasi masyarakat daerah sepertinya terabaikan. Bahkan pemerintah pusat sering menganggapnya sebagai penghambat pembangunan Negara Kesatuan Republik Indonesia (NKRI). Banyak kasus yang merupakan akumulasi kekecewaan masyarakat daerah telah memicu konflik dan gerakan lokal untuk memisahkan diri dari NKRI, misalnya, Gerakan Aceh Merdeka (GAM), Negara Riau Merdeka (NRM), Republik Maluku Selatan (RMS), dan Organisasi Papua Merdeka (OPM). Semua itu disinyalir lebih bersumber dari adanya ketidakadilan pemerintah pusat terhadap daerah.

Oleh karena itu, salah satu fokus penting dalam amandemen tersebut adalah menentukan pola ideal hubungan pusat-daerah atau desentralisasi. Dari hasil Pembahasan di Majelis Permusyawaratan Rakyat Republik Indonesia (MPR-RI) mengenai pola baru desentralisasi ini kemudian keluarlah paket UU Otonomi Daerah pada tahun 1999 dan pembentukan lembaga baru khusus untuk perwakilan daerah tahun 2001. Lembaga baru ini selanjutnya dikenal dengan nama Dewan Perwakilan Daerah Republik Indonesia (DPD-RI).

Lahirnya Dewan Perwakilan Daerah (DPD) adalah harapan baru bagi seluruh rakyat dan masa depan demokrasi Indonesia. Melalui lembaga baru itu, ruang aspirasi rakyat daerah dalam proses politik nasional masih bisa diperjuangkan dengan cara lain. Secara substansi, lahirnya DPD adalah dalam upaya menciptakan sistem mekanisme checks and balances di antara lembaga-lembaga yang mewakili rakyat dan lembaga-lembaga yang mewakili wilayah. DPD juga dipandang sebagai koreksi atau penyempurnaan sistem utusan daerah di MPR, karena masyarakat menginginkan suatu lembaga yang dapat merepresentasikan daerahnya sejalan dengan semangat otonomi daerah.

Lembaga DPD dibentuk untuk menjamin keterwakilan daerah yang merupakan salah satu elemen penting bagi pemeliharan NKRI. Lembaga DPD diatur secara khusus dalam UUD 1945 pada Pasal 22C, 22D, 22E, dan

' Jimly Assidiqie. Kuliah Umum Hukum Tata Negara, Auditorium Djokosoetono. Fakultas Hukum Universitas Indonesia, 18 Mei 2006. 
23F. Pada Pasal 22C ayat (1) menyatakan bahwa "anggota perwakilan daerah dipilih dari setiap provinsi melalui pemilihan umum". ${ }^{2}$ Hal ini menegaskan perwakilan daerah adalah perwakilan daerah provinsi bukan daerah kabupaten atau kota, dan dipilih langsung oleh rakyat melalui pemilihan umum.

Kehadiran DPD sebagai badan legislatif kedua perlu mendapat apresiasi positif dari semua pihak sebagai langkah penting dalam menata sistem pemerintahan yang demokratis. Sebagaimana falsafah dasar negara Indonesia yaitu Pancasila, maka diharapkan setiap daerah dapat berperan serta dalam pembangunan dan tentunya keberadaan wakilnya yaitu DPD sangat diperlukan.

\section{Pokok Permasalahan}

Untuk mencapai hasil yang diharapkan dan untuk lebih terarahnya penulisan karya tulis ilmiah ini, maka penulis membuat pembatasan mengenai masalah yang akan dibahas. Permasalahan dalam karya tulis ilmiah ini, difokuskan untuk melihat bagamaimana Undang-Undang Dasar 1945 setelah amademen IV tersebut mengatur mengenai wewenang dari Dewan Perwakilan Daerah serta bagaimana seharusnya peraturan tersebut disusun agar dapat memberikan wewenang yang lebih dari Dewan Perwakilan Daerah tersebut.

Berdasarkan latar belakang yang telah dikemukakan sebelumnya, maka penulis merumuskan pokok-pokok permasalahan sebagai berikut:

1. Pasal-pasal manakah yang perlu diamandemen dalam UndangUndang Dasar 1945 agar dapat memperkuat peranan dan kedudukan dari Dewan Perwakilan Daerah Republik Indonesia?

2. Akibat apakah yang dapat ditimbulkan dari amandemen UndangUndang Dasar 1945 terhadap peranan dan kedudukan dari Dewan Perwakilan Daerah Republik Indonesia?

\section{Tujuan Penelitian}

\section{A. Tujuan Umum}

Tujuan dari penelitian ini secara umum adalah untuk mengetahui bagaimana seharusnya peraturan mengenai peranan dan kedudukan

2 Indonesia. Undang-Lindang Dasar Republik Indonesia Tahun 19+5. Pasal 22C. 
dari Dewan Perwakilan Daerah agar dapat berperan dalam pengembangan daerah-daerah di Indonesia.

\section{B. Tujuan Khusus}

Dalam mengambil pembahasan permasalahan, penulis mempunyai beberapa tujuan khusus penelitian sebagai berikut:

1. Mengetahui dan memahami pasal-pasal dalam Undang-Undang Dasar 1945 yang perlu diamandemen agar dapat memperkuat peranan dan kedudukan dari Dewan Perwakilan Daerah Republik Indonesia;

2. Mengetahui dan memahami akibat yang dapat ditimbulkan dari amandemen Undang-Undang Dasar 1945 terhadap peranan dan kedudukan dari Dewan Perwakilan Daerah Republik Indonesia.

\section{Metode Penelitian}

\section{A. Jenis Penelitian}

Penelitian yang dilakukan dalam karya tulis ilmiah ini adalah berupa penelitian hukum normatif, karena yang diteliti adalah bahan pustaka atau sekunder, yang mencakup bahan hukum primer, sekunder, dan tertier. Ditinjau dari sifatnya, penelitian pada karya tulis ilmiah ini bersifat deskriptif-analitis.

\section{B. Teknik Pengumpulan Data}

Berdasarkan atas tempat diperolehnya, data dalam penelitian ada dua macam, yaitu data yang diperoleh dari masyarakat dan data yang diperoleh dari kepustakaan. ${ }^{3}$ Data yang diperoleh dari masyarakat dinamakan data primer, sedangkan data yang diperoleh dari kepustakaan disebut data sekunder.

Teknik pengumpulan data yang diterapkan pada karya tulis ilmiah ini adalah:

1. Penelitian kepustakaan (library research)

Penelitian kepustakaan dilakukan dengan cara mencari dan mengkaji bahan-bahan kepustakaan, yang berdasarkan kekuatan

${ }^{3}$ Ibid., hal. 51 
mengikatnya meliputi bahan primer berupa peraturan perundangundangan yang berkaitan dengan Dewan perwakilan Daerah , bahan sekunder berupa buku, makalah, artikel, internet, dan bahan tertier, yaitu bahan yang menunjang bahan primer dan bahan sekunder, seperti kamus hukum.

2. Wawancara (interview)

Disamping penelitian kepustakaan, untuk memperoleh data penulis juga melakukan wawancara dengan narasumber yang mengerti serta menguasai permasalahan mengenai struktur dan wewenang Dewan Perwakilan Daerah (DPD), yaitu Prof. Dr. Maria Farida Indriati, S.H., M.H.

\section{Peranan dan Kedudukan Dewan Perwakilan Daerah}

\section{A. Sejarah Terbentuknya Dewan Perwakilan Daerah}

Pembentukan lembaga Dewan Perwakilan Daerah (DPD) diawali dengan sejalannya pemberlakuan kebijakan otonomi daerah, sehingga posisi tawar daerah terhadap pemerintah pusat semakin kuat. Kelahiran DPD tidak hanya berfungsi sebagai representasi masyarakat lokal saja, tetapi juga mempunyai misi untuk mengapresiasikan kepentingan-kepentingan daerah. Sementara itu, peluang untuk mempererat hubungan pusat dan daerah termasuk dalam menjaga integrasi dan keutuhan bangsa dapat terjaga dengan baik.

Hal-hal yang menjadi latar belakang pembentukan Dewan Perwakilan Daerah dapat disebutkan sebagai berikut: ${ }^{4}$

1. Memperkuat ikatan daerah-daerah dalam wadah negara kesatuan Republik Indonesia dan memperteguh persatuan kebangsaan seluruh daerah;

2. Meningkatkan agregasi dan akomodasi aspirasi dan kepentingan daerah-daerah dalam perumusan kebijakan nasional berkaitan dengan negara dan daerah-daerah;

3. Meningkatkan percepatan demokrasi, pembangunan dan kemajuan daerah-daerah secara serasi dan seimbang;

4. Membangun dan menampung perwakilan daerah-daerah yang memadai untuk memperjuangkan aspirasi dan kepentingan daerah dalam lembaga legislatif.

${ }^{4}$ Intsiawati Ayus, "Menapak Tahun Pertama: DPD Instrumen Indonesia Baru”. (Jakarta: The Peripheral Institute dan Proklamasi Publishing House, 2005), Cet. 1. hal. 33. 


\section{B. Peranan Dewan Perwakilan Daerah}

DPD dapat mengajukan rancangan undang-undang kepada DPR yang berkaitan dengan otonomi daerah, pembentukan dan pemekaran. dan penggabungan daerah, pengelolaan sumber daya alam, dan sumber daya ekonomi lainnya serta berkaitan dengan perimbangan keuangan pusat dan daerah. Hal tersebut dicantumkan dalam pasal $22 \mathrm{D}$ ayat (1) UUD 1945. ${ }^{5}$ Rancangan undang-undang yang diajukan DPD tersebut akan dibahas bersama DPR sesuai dengan tata tertib DPR sebagaimana tercantum dalam pasal $22 \mathrm{D}$ ayat (2) UUD $1945 .^{6}$

Proses legislasi, DPD diundang oleh DPR untuk melakukan pembahasan bersama dengan pemerintah tentang Rancangan Undangundang yang diajukan oleh DPD pada awal pembicaraan tingkat I sesuai dengan tata tertib DPR. Pembicaraan tingkat I ini dilakukan untuk menyampaikan pandangan dan pendapat DPD terhadap Rancangan Undang-undang yang diajukannya serta tanggapan atas pandangan dan pendapat dari masing-masing lembaga. Pandangan tersebut akan menjadi bahan bagi DPR dan pemerintah dalam melakukan pembahasan atas Rancangan Undang-undang yang diajukan oleh DPD.

Apabila Rancangan Undang-undang yang diajukan oleh DPD tersebut disahkan menjadi Undang-undang, maka DPD berperan sebagai pengawas atas pelaksanaan Undang-undang tersebut. Ketentuan mengenai pengawasan DPD dalam pelaksanaan Undangundang yang berkaitan dengan otonomi daerah, pembentukan, pemekaran, dan penggabungan daerah, hubungan pusat dan daerah. pengelolaan sumber daya alam dan sumber daya ekonomi lainnya diatur dalam Pasal 22D ayat (3) Undang-Undang Dasar 1945.

Apabila dilihat dari perspektif hukum tata negara, kedudukan Dewan Perwakilan Daerah (DPD) dan Dewan Perwakilan Rakyat (DPR) sebagai wakil rakyat memang memiliki kedudukan yang sama sebagai lembaga negara. Namun perbedaan antara kedua lembaga tersebut adalah hakekat kepentingan yang diwakili masing-masing lembaga. Dewan Perwakilan Rakyat dimaksudkan untuk mewakili rakyat, sedangkan Dewan Perwakilan Daerah dimaksudkan untuk

\footnotetext{
'Indonesia. Undang-lindang Dasar 1945. Pasal 22D ayat (1).

${ }^{6}$ Ibid., Pasal 22D ayal (2)

${ }^{7}$ Ihid.. Pasal 22D ayat (3)
} 
mewakili daerah-daerah. Berdasarkan keterangan dari Prof. Dr. Maria Farida Indriati, SH., MH., menyatakan bahwa sistem lembaga perwakilan rakyat di Indonesia adalah bikameral karena hanya terdiri dari dua kamar, yaitu DPR dan DPD. ${ }^{8}$ Hal ini berarti sebenarnya kedudukan Dewan Perwakilan Daerah seimbang dengan Dewan Perwakilan Rakyat.

Dalam menjalankan peranannya, Dewan Perwakilan Daerah harus mengutamakan kepentingan daerah sebagai keseluruhan, terlepas dari kepentingan individu-individu rakyat kepentingannya seharusnya disalurkan melalui Dewan Perwakilan Rakyat. Namun pengertian kepentingan daerah itu tentunya tidak terlepas adanya kepentingan individu yang hidup di daerah itu.

\section{Kedudukan Dewan Perwakilan Daerah}

\section{Kedudukan Dewan Perwakilan Daerah dalam Majelis Permusyawaratan Perwakilan}

Kedudukan dan kewenangan Dewan Perwakilan Daerah yang terbatas, sebagaimana dalam Pasal 22 D, dalam proses politiknya mengalami perdebatan yang cukup sengit dalam sidang sidang komisi. Tanggapan para anggota Panitia Ad Hoc (PAH) I BP MPR terhadap tim ahli yang diberi kesempatan untuk menyampaikan pandangannya, pada umumnya, anggota PAH I MPR terkesan difensif dengan bersikukuh menempatkan DPR lebih superior dibadingkan dengan DPD. ${ }^{9}$ Menurut Jakob Tobing (F-PDIP), gagasan bikameral sebagaimana yang dikatakan oleh tim ahli, hanya cocok untuk negara federal, namun untuk negara kesatuan, lebih tepat bila menggunakan sistem bikameral lemah. Sedangkan terhadap gagasan persamaan kekuasaan legislasi antar DPR dan DPD, anggota PAH I MPR mengkhawatirkan munculnya persaingan antara kedua lembaga yang berujung pada situasi dead-lock, atau tidak berujung disahkannya suatu rancangan undang-undang. ${ }^{10}$

${ }^{8}$ Wawancara dilakukan pada tanggal 7 Mei 2007 di Auditorium Djoko Soetono. Fakultas Hukum Universitas Indonesia pukul 16.05 WIB.

${ }^{9}$ Risalah Rapat Panitia Ad Hoc I Buku II, 3A: Buku II, 4A: Buku II, 5A: Buku II, 6A: Buku II, 7A: dan Buku II, 8A. Diterbitkan oleh Sekretariat Jenderal MPR RI 2001.

${ }^{10} \mathrm{Ibid}$. 
Tanggapan Agun Gunandjar Sudarsa (F-Golkar) tentang kedudukan DPR dan DPD adalah:"

"Menurut pendapat kami, kekuasaan legislatif harus tetap berada di Dewan Perwakilan Rakyat, kalau bicaranya dalam konteks negara kesatuan. Dewan Perwakilan Daerah boleh memiliki kekuasaan legislatif tapi terbatas, yaitu hanya sebatas masalah kepentingan daerah... Begitu pula menyangkut fungsinya dan anggarannya."

Selanjutnya Sudjiarto (F-Utusan Golongan) menambahkan tentang kesejajaran DPD dan DPR yaitu: ${ }^{12}$

“...Jangan sampai ada arjuna kembar. Kalau DPD dan DPR itu sama-sama mempunyai kekuasaan legislatif, sama-sama dipilih, lalu apa bedanya?... Ini perlu dipikirkan untuk menjamin negara kebangsaan."

\section{Keanggotaan Dewan Perwakilan Daerah}

Menurut Undang-Undang Nomor 22 Tahun 2003 Tentang Susunan dan Kedudukan MPR, DPR, dan DPD serta DPRD maka keanggotaan DPD terdiri atas wakil-wakil daerah provinsi yang dipilih melalui pemilihan umum. Anggota DPD setiap provinsi ditetapkan sebanyak 4 orang. Jumlah seluruh anggota DPD tidak lebih dari $1 / 3$ anggota DPR. Keanggotaan DPD diresmikan dengan Keputusan Presiden. Anggota DPD berdomisili di daerah pemilihannya dan selama sidang bertempat tinggal di ibukota Negara Republik Indonesia. Masa jabatan anggota DPD adalah 5 tahun bersamaan pada saat anggota DPD yang baru mengucapkan sumpah dan janji.

Posisi seorang anggota DPD sebenarnya sangatlah kuat. Dalam sistem politik Amerika Serikat, wakil negara bagian ini dikenal dèngan nama Senator. Dibandingkan dengan anggota DPR yang umumnya tidak memenuhi bilangan pembagi pemilih (BPP) dalam pemilu, anggota DPD justru memiliki dukungan yang lebih riil dan legitimatif. Oleh karena itu, sangat wajar jika

"Ibid., hal. 272-273.

${ }^{12}$ Ibid., hal. 281-282. 
masyarakat atau konstituen menaruh harapan besar pada anggota DPD.

Namun sayangnya, kedudukan institusi DPD dalam struktur politik nasional ternyata masih dibatasi Undang-undang Dasar dan Undang-undang. DPD kedudukannya masih belum setara dengan DPR. Jika diamati peran wakil daerah ini tidak lebih sekedar lembaga pertimbangan saja.

Anggota DPD merupakan calon perseorangan yang dilengkapi dukungan yang diperlihatkan dengan pengumpulan KTP dalam jumlah tertentu. Kemudian calon anggota DPD diseleksi oleh KPU sebagai lembaga yang menyelenggarakan pemilu. Setelah lolos seleksi dari KPU maka anggota DPD baru dipilih langsung oleh rakyat melalui pemilihan umum dengan sistem distrik berwakil banyak.

Kedudukan DPD sebagai lembaga negara yang sejajar dengan lembaga negara lainnya antara lain DPR, Presiden, Mahkamah Agung, BPK. Utusan Daerah bukan merupakan lembaga negara tersendiri seperti dalam DPD. Dalam pelaksanaannya utusan daerah dalam MPR diwujudkan dalam sebuah fraksi sebagai fraksi tersendiri dalam MPR maupun bergabung dengan fraksi lainnya. Sedangkan fungsi dan wewenang DPD lebih besar dari utusan daerah karena selain tetap sebagai MPR, anggota DPD juga memiliki kewenangan dalam bidang-bidang tertentu sebagaimana tercantum dalam Pasal 22D, Pasal 23 ayat 2, Pasal 23 E, dan Pasal 23 F UUD 1945.

\section{Amandemen Undang-Undang Dasar 1945}

\section{A. Pasal-pasal yang Perlu Diamandemen MPR-RI}

Sebagaimana dikemukakan dalam Undang-Undang Dasar 1945, Dewan Perwakilan Daerah (DPD) merupakan lembaga tinggi negara yang dibentuk untuk mewakili daerah-daerah yang ada di wilayah Negara Kesatuan Republik Indonesia. Sebagaimana wakil rakyat pada tingkat daerah, seharusnya wewenang dari Dewan Perwakilan Daerah dapat lebih ditingkatkan agar memiliki peranan dan kedudukan yang sama dengan Dewan Perwakilan Rakyat. Hal ini disebabkan masih banyaknya daerah tertinggal yang ada di wilayah Indonesia.

Upaya untuk menyeimbangkan kekuasaan dan mengontrol kinerja DPR, yang pasca amandemen pertama UUD 1945 sangat dominan dan superioritas. Permasalahannya adalah keberadaan DPD hasil Pemilu 
2004 lalu ternyata belum memenuhi harapan politik sebagian besar masyarakat perihal check and balances di parlemen. ${ }^{13}$ Alih-alih keberadaan DPD diharapkan menjadi lembaga penyeimbang dan mampu menjadi mitra yang setara dengan DPR, DPD justru hanya menjadi lembaga tinggi tanpa taring dan gigi. Fungsinya sekadar menjadi pelengkap. Karenanya penguatan eksistensi DPD di parlemen adalah sesuatu yang tidak bisa ditunggu.

Mengenai pendirian lembaga DPD, ada sebuah doktrin yang diucapkan oleh Intsinawati Ayus yầng dalam bukunya yaitu Menapak Tahun Pertama: DPD Instrumen Indonesia Baru yang mengatakan bahwa lembaga DPD adalah membangun dan menampung perwakilan daerah-daerah yang memadai untük memperjuangkan aspirasi dan kepentingan daerah dalam lembaga legislatif. Dalam pernyataan tersebut dapat dikatakan bahwa kehadiran DPD merupakan wakil rakyat daerah dalam parlemen dan seharusnya memiliki wewenang yang tidak terbatas pada otonomi daerah. Kewenangan DPD seharusnya diperluas pada kewenangan legislasi yang dimiliki oleh wakil rakyat.

Peraturan perundang-undangan yang dibuat oleh Dewan Perwakilan Rakyat (DPR) merupakan peraturan yang akan berlaku nasional baik dari ibukota negara hingga pedesaan sehingga dalam setiap pembahasan diperlukan wakil daerah yang dalam hal ini adalah DPD. Untuk itu, ada beberapa pasal yang seharusnya dapat diamandemen dan amandemen dari pasal tersebut akan memantapkan posisi bahwa Indonesia memiliki sistem lembaga perwakilan bikameral.

Salah satu pasal yang perlu diamandemen adalah Pasal 22D ayat (2) Undang-Undang Dasar 1945 yang menyatakan bahwa:

"Dewan Perwakilan Daerah ikut membahas Rancangan Undang-undang yang berkaitan dengan otonomi daerah; hubungan pusat dan daerah; pembentukan, pemekaran, dan penggabungan daerah; pengelolaan sumber daya alam dan sumber daya ekonomi lainnya, serta perimbangan keuangan pusat dan daerah; serta memberikan pertimbangan kepada Dewan Perwakilan Rakyat atas Rancangan Undang-undang Anggaran Pendapatan dan

$13<$ http://www.pikiran-rakyat.com/cetak/2005/0805/09/0801.htm>, diakses pada tanggal 2 Juni 2007. 


\section{Belanja Negara dan Rancangan Undang-undang yang berkaitan dengan pajak, pendidikan, dan agama."}

Dalam hal ini salah satu hal yang kontroversi adalah DPD yang telah mengajukan Rancangan Undang-undang hanya dapat ikut membahas sebatas untuk memperoleh tanggapan dari DPR dan Pemerintah. Dengan kata lain, segala kebutuhan daerah yang dicantumkan dalam Rancangan Undang-undang yang diajukan oleh DPD, meskipun sudah disetujui pada sidang tingkat $\mathrm{I}$, belum tentu menghasilkan produk Undang-undang yang sesuai dengan apa yang dirancangkan. Hal ini dikarenakan dalam sidang komisi yang membahas mengenai Rancangan Undang-undang, terdapat revisirevisi yang dilakukan agar memperoleh persetujuan dari seluruh dewan yang membahas mengenai RUU tersebut.

Selain terbatasnya keikutsertaan DPD dalam membahas mengenai Rancangan Undang-undang yang diajukannya, DPD seharusnya ikut serta dalam pembahasan Rancangan Undang-undang di luar permasalahan otonomi daerah. Hal ini disebabkan penyusunan produk Undang-undang sebagaimana dijelaskan sebelumnya, diberlakukan secara nasional dan tidak sepantasnya suatu produk hukum yang berlaku secara nasional hanya dibahas oleh Dewan Perwakilan Rakyat yang berada di wilayah pusat. Pemberlakuan peraturan perundangundangan secara nasional tentunya harus tetap memperhatikan norma dasar (staatsgrundnorm) yang dimiliki oleh Indonesia yaitu Pancasila. Dalam hal ini sila-5 Pancasila menyatakan bahwa "Keadilan sosial bagi seluruh rakyat Indonesia" yang bermakna bahwa setiap kebijakan yang ada haruslah mencerminkan keadilan bagi seluruh rakyat yang berada dalam teritorial Indonesia.

Berdasarkan sila-5 Pancasila tersebut sebagai norma dasar tertinggi, maka keikutsertaan daerah dalam pembahasan Rancangan Undang-undang diperlukan untuk memperoleh rumusan Undangundang yang dapat berlaku secara nasional dan diterima oleh seluruh rakyat Indonesia. Partisipasi daerah dalam pembahasan Rancangan Undang-undang dapat menyelesaikan permasalahan dalam perumusan peraturan perundang-undangan yang tepat dan mampu diterima oleh masyarakat luas. Oleh karena itu maka rumusan yang paling tepat agar dapat mengakomodir seluruh rakyat Indonesia maka dapat berupa:

"Dewan Perwakilan Daerah ikut membahas setiap Rancangan Undang-undang bersama-sama dengan pihak Dewan Perwakilan Rakyat dan Pemerintah, dengan tidak 
terbatas pada Rancangan Undang-undang yang berkaitan dengan otonomi daerah atau pembangunan daerah saja. "

Amandemen atau perubahan pada Pasal 22D ayat (2) UndangUndang Dasar 1945 tersebut dapat memberikan makna bahwa dalam pembahasan setiap Rancangan Undang-undang, tidak hanya sebatas DPR dan Pemerintah saja tetapi juga menyertakan DPD. Hal inilah yang akan melaksanakan Prinsip Keadilan Sosial sebagaimana yang terkandung dalam sila kelima Pancasila dan Pembukaan UUD 1945 sebagai norma dasar dari tata hukum di Indonesia.

Perubahan pada Pasal 22D ayat (2) ini lebih menekankan bahwa DPD tetap berpartisipasi dalam setiap penyusunan produk hukum yang dibentuk oleh badan legislatif. Dengan adanya perubahan atau amandemen pada Pasal 22D ayat (2) Undang-undang Dasar 1945 tersebut, diharapkan fungsi dan wewenang DPD menjadi semakin luas dan tidak terbatas pada penyusunan peraturan perundang-undangan yang hanya membahas mengenai permasalahan yang berkaitan dengan otonomi daerah dan pembangunan daerah. Dengan kata lain, fungsi dan wewenang DPD juga ikut serta dalam pembentukan peraturan perundang-undangan yang diharapkan dapat lebih diterima oleh masyarakat apabila Undang-undang tersebut berkekuatan hukum tetap.

Dengan adanya perubahan pada Pasal 22D ayat (2) UndangUndang Dasar 1945 tersebut, tentunya tidak menutup kemungkinan dari perubahan pada Pasal 22D ayat (3) Undang-Undang Dasar 1945 yang dimana menyatakan sebagai berikut:

"Dewan Perwakilan Daerah dapat melakukan pengawasan atas pelaksanaan undang-undang mengenai: otonomi daerah, pembentukan, pemekaran dan penggabungan daerah, hubungan pusat dan daerah, pengelolaan sumber daya alam dan sumber daya ekonomi lainnya, pelaksanaan anggaran pendapatan dan belanja negara, pajak, pendidikan, dan agama serta menyampaikan hasil pengawasannya itu kepada Dewan Perwakilan Rakyat sebagai bahan pertimbangan untuk ditindaklanjuti."

Dalam ketentuan pasal tersebut, perlu dilakukan perubahan agar pengawasan yang dilakukan atas pelaksanaan Undang-undang tidak hanya terbatas pada ketentuan yang membahas mengenai otonomi daerah, pembentukan, pemekaran, pembangunan, dan pengelolaan daerah, melainkan seluruh Undang-undang yang dibentuk oleh lembaga legislatif. Hal ini tentunya dapat merubah sebagian isi pasal tersebut menjadi: 
"Dewan Perwakilan Daerah dapat melakukan pengawasan atas pelaksanaan undang-undang tidak terbatas mengenai: otonomi daerah, pembentukan, pemekaran dan penggabungan daerah, hubungan pusat dan daerah, pengelolaan sumber daya alam dan sumber daya ekonomi lainnya, pelaksanaan anggaran pendapatan dan belanja negara, pajak, pendidikan, dan agama serta menyampaikan hasil pengawasannya itu kepada Majelis Permusyawaratan Rakyat sebagai bahan pertimbangan untuk ditindaklanjuti."

Perubahan yang dilakukan terhadap Pasal 22D ayat (3) UndangUndang Dasar 1945 adalah sebagai lanjutan dari ketentuan pada Pasal 22D ayat (2) Undang-Undang Dasar 1945. Hal tersebut dilakukan agar dapat memperkuat peranan dari Dewan Perwakilan Daerah (DPD) yang selain ikut serta dalam pembentukan produk hukum bersama dengan lembaga legislatif, tetapi juga ikut serta dalam menyampaikan hasil pengawasannya itu kepada Majelis Permusyawaratan Rakyat. Hal ini dilakukan agar Dewan Perwakilan Daerah memiliki wewenang untuk memberikan laporan hasil pengawasan kepada pihak Majelis Permusyawaratan Rakyat.

\section{B. Akibat yang Ditimbulkan Apabila Amandemen UUD 1945 Dilakukan}

Berdasarkan perubahan yang dilakukan terhadap Pasal 22D ayat (2) Undang-Undang Dasar 1945, maka perubahan terhadap wewenang Dewan Perwakilan Daerah (DPD) akan bertambah dan tidak sebatas pada pembahasan terhadap Rancangan Undang-undang yang berkaitan dengan otonomi daerah dan pembangunan daerah. Wewenang legislasi DPD menjadi lebih diperluas pada pembahasan setiap Rancangan Undang-undang baik yang berkaitan dengan otonomi daerah maupun yang bukan berkaitan dengan otonomi daerah.

Pembahasan Rancangan Undang-undang dapat lebih efektif apabila diikuti oleh Dewan Perwakilan Daerah (DPD). Hal ini dikarenakan Undang-undang yang sudah dibentuk oleh lembaga legislatif yang dalam hal ini adalah DPR bersama dengan pemerintah masih belum mampu mengakomodir seluruh elemen masyarakat. Setiap pasal dalam Rancangan Undang-undang tersebut dapat disesuaikan dengan kondisi masyarakat dari setiap daerah yang berada di wilayah negara Indonesia. Ketentuan dalam pasal-pasal Rancangan Undang-undang yang disusun oleh lembaga legislatif tentunya akan 
mudah diterima oleh masyarakat sehingga pelaksanaan dari Undangundang yang dibentuk oleh lembaga legislatif akan lebih optimal.

Selain lebih mudah diterima dan pelaksanaannya lebih optimal, produk hukum yang dibentuk dengan bantuan dari Dewan Perwakilan Daerah (DPD) akan mudah untuk diawasi dalam pelaksanaannya. Amandemen Pasal 22D ayat (3) Undang-Undang Dasar 1945 menyebabkan pelaksanaan pengawasan akan semakin luas yakni pada setiap Undang-undang yang sudah berlaku dan berkekuatan hukum tetap. Pengawasan yang dilakukan tersebut dapat menjadi semakin leluasa apabila kewenangan Dewan Perwakilan Daerah (DPD) tidak dibatasi sebagaimana tercantum dalam Pasal 22D ayat (3) UndangUndang Dasar sebelumnya. Dengan kata lain, tentunya setiap pelaksanaan Undang-undang oleh lembaga eksekutif akan semakin diawasi secara ketat dan akan memperkecil terjadinya pelanggaran. $\mathrm{Hal}$ ini tentu akan mempermudah proses pembangunan dan pemekaran daerah-daerah yang masih belum mendapatkan perhatian dari aparat pemerintah.

Berdasarkan penelitian penulis, penambahan wewenang Dewan Perwakilan Daerah (DPD) dalam pembahasan Rancangan Undangundang yang tidak terbatas pada otonomi daerah tersebut selanjutnya akan membuat peran dari Dewan Perwakilan Daerah (DPD) semakin penting dan dibutuhkan dalam setiap proses legislasi. Peranan tersebut adalah dimana DPD memiliki wewenang untuk membantu DPR dan pemerintah dalam membentuk Undang-undang. Dengan peranan yang bertambah tersebut, maka DPR dan pemerintah dapat membentuk suatu Undang-undang yang memenuhi asas keadilan. Keterbatasan wewenang DPD pada Pasal 22D ayat (2) UUD 1945 Amandemen IV menyebabkan produk hukum yang dibuat oleh badan legislatif tidak diterima oleh masyarakat. Selain itu, Dewan Perwakilan Rakyat (DPR) akan semakin mudah dalam melakukan check and balances terhadap kebijakan-kebijakan lembaga eksekutif apabila melakukan pelanggaran. Selama ini, apabila terjadi pelanggaran pada tingkat daerah seringkali tidak dilakukan suatu tindakan yang tegas karena pengawasan hanya terbatas pada tingkat pusat, sehingga dengan perubahan terhadap Pasal 22D ayat (3) UUD 1945 wewenang DPR dalam melakukan check and balances akan semakin mudah. 


\section{Penutup}

\section{A. Simpulan}

Berdasarkan penelitian yang dilakukan terhadap ketentuan yang mengatur mengenai peranan dan kedudukan Dewan Perwakilan Daerah dalam UUD 1945, dapat ditarik kesimpulan untuk menjawab pokok permasalahan yang disebutkan sebelumnya, yaitu:

1. Ketentuan pasal yang perlu diamandemen adalah Pasal 22D Undang-undang Dasar 1945 ayat (2) dan (3) dimana ketentuan dalam ayat tersebut, sangat membatasi peranan dan kedudukan dari Dewan Perwakilan Daerah yang hanya terbatas pada tingkat daerah. Hal ini terlihat dimana Pasal 22D ayat (2) dan (3) UUD 1945 hanya memberikan batasan dalam pembahasan Rancangan Undang-undang dan pengawasan pelaksanaan Undang-undang. Ketentuan ini akan menghambat proses pembangunan daerah karena setiap Undang-undang yang berlaku tentunya akan berlaku juga di setiap daerah dalam wilayah Indonesia. Dengan kata lain, dapat dikatakan bahwa daerah juga membutuhkan lembaga yang dapat menyuarakan aspirasinya kepada tingkat pusat;

2. Akibat yang dapat ditimbulkan dengan adanya amandemen Undang-undang Dasar 1945 yaitu dimana lembaga legislatif akan semakin mudah dalam penyusunan Rancangan Undang-undang. Hal ini disebabkan lembaga legislatif dapat merangkul seluruh daerah yang ada di Indonesia, sehingga Rancangan Undangundang yang dibentuk oleh lembaga legislatif akan dapat berlaku di seluruh wilayah Indonesia. Selain keberlakuan secara menyeluruh, pengawasan terhadap pelaksanaan Undang-undang pada tingkat daerah dapat diawasi dengan baik, hal ini dapat memperkecil kesewenang-wenangan aparat pemerintah untuk melakukan tindakan yang merugikan rakyat daerah.

\section{B. Saran}

Berdasarkan penelitian yang sudah dilakukan tentang peranan dan kedudukan Dewan Perwakilan Daerah (DPD) tersebut, penulis memberikan beberapa saran dimana yang pertama adalah Dewan Perwakilan Daerah (DPD) harus diperluas ruang lingkup geraknya, hal ini disebabkan masih banyak daerah yang terlantar dan membutuhkan peranan DPD untuk menyuarakan aspirasinya kepada tingkat pusat. Selain itu juga DPD harus ikut dalam setiap pembahasan Rancangan 
Undang-undang. Hal ini disebabkan Rancangan Undang-undang akan mengikat seluruh elemen masyarakat dan keberlakuan dapat menjadi optimal apabila DPD juga menjadi salah satu pembahas Rancangan Undang-undang.

Selain peranan tersebut, harus juga diperhatikan bentuk lembaga perwakilan di Indonesia yang tetap harus mempertahankan konsep bikameral. Hal ini dikarenakan peranan Majelis Permusyawaratan Rakyat tidak memiliki peranan sebagai lembaga tertinggi negara dan anggotanya terdiri atas DPR dan DPD. Dengan kata lain, seharusnya peranan DPD dan DPR disejajarkan karena keduanya akan saling melengkapi agar setiap kebijakan yang dibentuk oleh lembaga legislatif akan dapat mengikat seluruh elemen dalam masyarakat. 


\section{Daftar Pustaka}

\section{Buku-buku, Makalah, dan Kamus:}

Amir, Makmur dan RD Purnomowati. Lembaga Perwakilan Rakyat, Jakarta: Pusat Studi Hukum Tata Negara UI, 2005.

Assidiqie, Jimly. Kuliah Umum Hukum Tata Negara, Auditorium Djoko Soetono, Fakultas Hukum Universitas Indonesia, 18 Mei 2006.

Ayus, Intsiawati. Menapak Tahun Pertama, DPD Instrumen Indonesia Baru Jakarta: The Peripheral Institute dan Proklamasi Publishing House, 2005.

Soekanto, Soejono. Pengantar Penelitian Hukum, Jakarta: Universitas Indonesia (UI-Press), 1986.

Risalah Rapat Panitia Ad Hoc I Buku II, 3A; Buku II, 4A; Buku II, 5A; Buku II, 6A; Buku II, 7A; dan Buku II, 8A. Diterbitkan oleh Sekretariat Jenderal MPR RI 2001.

\section{Peraturan Perundang-undangan:}

Indonesia, Undang-Undang Dasar Republik Indonesia Tahun 1945.

\section{Artikel, Majalah, Internet:}

$<$ http://www.dpd.go.id/myblog/ news.php?uid=14\&id=82>, diakses pada tanggal 22 Juni 2006.

<http://www.pikiran-rakyat.com/cetak/2005/0805/09/0801.htm>, diakses pada tanggal 2 Juni 2007.

$<$ http://www.suarakarya-online.com/news.html?id=166602>, diakses pada tanggal 22 Juni 2006. 